\title{
De-Population And Re-Population: A Demographic Analysis Of Turn-Around Counties Of The South\#
}

\author{
EDward E. Cahill* and URMIL SALUJA**
}

\section{INTRODUCTION}

Amid outcries concerning a population explosion of the 1950's and the 1960's there was an out-migration from rural areas of the United States, particularly of blacks. This increasing metropolitanization of the population during the 1950's and 1960's led Congress to declare in 1972 that:

"Substantial out-migration from rural to urban areas is aggravating the economic and social conditions of areas of out-migration as well as central cities. National economic policy should anticipate and take into account the dislocation of jobs due to technological change, shifting trade patterns, environmental adjustments, and the continuing need to make geographical adaptations to economic problems."

(Beckman and Harding, 1973)

Despite the dire predictions of doomsdayers of "overpopulation," almost half the counties of the United States incurred population losses during the 1950's and 1960's. More often than not, the losses sustained by these counties were of those people whose youth, strength, ambition, and education might have increased the productivity within such counties had other economic and educational opportunities been available to them at the places of origin. Data from the Survey of Economic Opportunity studies indicate that migrants from rural to urban areas are generally better educated, younger, and less likely to have work-limiting health conditions than non-migrants in the rural areas (Bowles, et al., 1973). The ensuing loss of the young, well-educated from rural areas tends to exaggerate the statistical characteristics of the population remaining in rural areas, such as low educational attainment, high fertility, high ratios of youth and aged dependency, and low labor force participation rates.

\footnotetext{
*Professor of Sociology, The University of Tennessee at Chattanooga.

**Institute for Behavioral Research, Graduate Studies Research Center, The University of Georgia, Athens, Georgia.

\#The research on which this paper is based is funded by the National Science Foundation, Research Applied to National Needs, under the project title "Population Redistribution: A Challenge for Policy and Planning," conducted at The University of Georgia.

Adaptation of paper presented at the Annual Meeting of the Southern Regional Science Association in Washington, D.C., April 3-5, 1974.
} 
The rate of growth of the population of the United States has declined noticeably during the last few years, but the concentration in selected areas has increased considerably. Thus, today approximately 55 percent of the population is located in counties within 50 miles of the major waterways - the Atlantic Coast, Pacific Coast, Gulf of Mexico, the Mississippi River, and the Great Lakes regions (Lee, 1973). While this increasing concentration presents problems of its own, it is not our purpose to tackle these problems of "overpopulation," but rather to look at the problems of the areas in the South that had been de-populated during this period.

Of more than 3,000 county units or equivalents, over 1,500 lost population between 1950 and 1960 and over 1,300 counties lost population during the 1960's (Table 1). An interesting reversal from population loss during the 1950's to gain during the 1960 's occurred in some 480 counties of the United States. Of these 480 counties, 292 were located in the South (Table 2). First discussed by Beale (1971), these turn-around counties have been classified with other counties of the United States for the decades 1950-60 and 1960-70 showing those which grew through natural increase and net in-migration, natural increase exceeding out-migration, and net in-migration exceeding natural decrease; and those which lost population through out-migration and natural decrease, natural decrease exceeding net in-migration, or net out-migration exceeding natural increase (Tables 1 and 2).

Hansen (1973) has descriptively analyzed the turn-around counties within very broad regional categorizations based on the geographic locations of these counties. He used the Population Trends Map of Counties of the United States, published by the Bureau of the Census, to identify the turn-around counties but did not differentiate components of change of these counties. Emphasizing changes in economic characteristics of turn-around counties, he neglects to control for changes produced through population dynamics. Thus, after analyzing the impact of the interstate highway system upon the turri-around counties, for example, Hansen states:

"The explanation for reversal does not appear to be related to highways or proximity to Standard Metropolitan Statistical Areas, but rather must be sought elsewhere."

(Hansen, 1973)

Indeed, it seemed logical to us as to Hansen and others considering the advantages of accessibility to metropolitan growth areas as a result of the placement of interstate highways, the relative costs of land, and the probabilities of an abundance of labor in rural areas (Bowles, 1966) that industries would be stimulated and in turn precipitate population growth in areas proximate to the freeway system that had been previously declining. In our analysis we found a rather large number of turnaround counties that were either on interstate highway systems or con- 
TABLE 1

Counties by Type of Population Change, United States 1950-60 and 1960-70*

\begin{tabular}{|c|c|c|c|c|c|c|c|c|c|}
\hline \multirow{3}{*}{ Population Change } & \multicolumn{8}{|c|}{$1960-70$} & \multirow{3}{*}{$\begin{array}{l}\text { Row } \\
\text { Total } \\
1950-60\end{array}$} \\
\hline & \multicolumn{4}{|c|}{ Increase } & \multicolumn{4}{|c|}{ Decrease } & \\
\hline & $a$ & $b$ & $c$ & Total & $x$ & $y$ & $z$ & Total & \\
\hline \multicolumn{10}{|l|}{ Increase: $1950-60$} \\
\hline \multicolumn{10}{|l|}{$a$-Net in-migration and } \\
\hline $\begin{array}{l}b \text {-Net out-migration, natural } \\
\text { increase greater than net }\end{array}$ & & & & & & & & & \\
\hline out-migration & 262 & 378 & 4 & 644 & - & - & 244 & 244 & 888 \\
\hline \multicolumn{10}{|l|}{$\begin{array}{l}c \text {-Net in-migration, natural } \\
\text { decrease less than }\end{array}$} \\
\hline net in-migration & - & 1 & - & 1 & - & - & - & - & 1 \\
\hline Total & 688 & 537 & 12 & 1,237 & - & - & 304 & 304 & 1,541 \\
\hline \multicolumn{10}{|l|}{ Decrease: $1950-60$} \\
\hline \multicolumn{10}{|l|}{$x$-Net out-migration and } \\
\hline $\begin{array}{l}y \text {-Net in-migration, natural } \\
\text { decrease greater than }\end{array}$ & & & & & & & & & \\
\hline net in-migration & - & 一 & - & 一 & - & - & - & 一 & - \\
\hline \multicolumn{9}{|l|}{$z$-Net out-migration, natural } & \\
\hline net out-migration & 209 & 247 & 22 & 478 & 83 & 6 & 956 & 1,045 & 1,523 \\
\hline Total & 210 & 247 & 23 & 480 & 84 & 6 & 956 & 1,046 & 1,526 \\
\hline \multicolumn{10}{|l|}{ Column Total } \\
\hline $1960-70$ & 898 & 784 & 35 & 1,717 & 84 & 6 & 1,260 & 1,350 & 3,067 \\
\hline
\end{tabular}

Sources: NSF-RANN Population Redistribution Project; 1960-70 CPS, Series P-25, No. 461, June 28, 1971; Gladys K. Bowles and James D. Tarver, Net Migration of the Population, 1950-60, by Age, Sex, and Color, 2 Volumes, Economic Research Service, U. S. Department of Agriculture, 1965, and related unpublished materials.

*In certain instances counties or independent cities were combined and treated as a single unit. Four county units (Knox, Ill., Montgomery, Iowa, and Patrick and Surry, Va.) are not included in this table due to code peculiarities for one decade.

tiguous to those counties crossed by interstates in the South. However, we also found that a considerable number of turn-arounds were not on the system (Table 3). Hansen's convenient grouping of turn-around counties into broad regional areas (for example, the Tennessee River Valley area, the Ozark area, etc.) did not offer sufficient explanation for the large number of turn-arounds falling outside of these geographic groupings. Additionally, his analysis provides no indication of the strength of the turn-around, that is, whether the growth found therein is likely to continue, nor whether it is possible to predict future turnaround areas from the factors analyzed. 
TABLE 2

Southern Counties by Type of Population Change 1950-60 and 1960-70

\begin{tabular}{|c|c|c|c|c|c|c|c|c|c|}
\hline \multirow{3}{*}{ Population Change } & \multicolumn{8}{|c|}{$1960 \cdot 70$} & \multirow{3}{*}{$\begin{array}{l}\text { Row } \\
\text { Total } \\
1950-60\end{array}$} \\
\hline & \multicolumn{4}{|c|}{ Increase } & \multicolumn{4}{|c|}{ Decrease } & \\
\hline & $a$ & $b$ & $c$ & Total & $x$ & $y$ & $z$ & Total & \\
\hline \multicolumn{10}{|l|}{ Increase: $1950-60$} \\
\hline \multicolumn{10}{|l|}{$a$-Net in-migration and } \\
\hline $\begin{array}{l}b \text {-Net out-migration, } \\
\text { natural increase greater }\end{array}$ & & & & & & & & & \\
\hline $\begin{array}{l}\text { than net out-migration } \\
\text { c-Net in-migration, } \\
\text { natural decrease less }\end{array}$ & 110 & 157 & 2 & 269 & - & - & 83 & 83 & 352 \\
\hline than net in-migration & - & - & - & - & - & - & - & - & - \\
\hline Total & 255 & 214 & 8 & 477 & - & - & 110 & 110 & 587 \\
\hline \multicolumn{10}{|l|}{ Decrease: $1950-60$} \\
\hline \multicolumn{10}{|l|}{$\begin{array}{l}x \text {-Net out-migration and } \\
\text { natural decrease }\end{array}$} \\
\hline $\begin{array}{l}y \text {-Net in-migration, } \\
\text { natural decrease greater }\end{array}$ & & & & & & & & & \\
\hline \multicolumn{10}{|l|}{$\begin{array}{l}z \text {-Net out-migration, } \\
\text { natural increase less }\end{array}$} \\
\hline than net out-migration & 122 & 159 & 11 & 292 & 23 & 1 & 479 & 503 & 795 \\
\hline Total & 122 & 159 & 11 & 292 & 23 & 1 & 479 & 503 & 795 \\
\hline \multicolumn{10}{|l|}{ Column Total } \\
\hline $1960-70$ & 377 & 373 & 19 & 769 & 23 & 1 & 589 & 613 & 1,382 \\
\hline
\end{tabular}

Source: University of Georgia, NSF-RANN Population Redistribution Project.

TABLE 3

Turn-Around Counties, South, by Metropolitan, Nonmetropolitan, and other Classifications.

\begin{tabular}{|c|c|c|c|c|c|c|c|}
\hline \multirow{3}{*}{$\begin{array}{l}\text { POPULATION } \\
\text { CHANGE } \\
\text { SOURCE }\end{array}$} & \multicolumn{2}{|c|}{ METROPOLITAN } & \multicolumn{4}{|c|}{ NONMETROPOLITAN } & \multirow{3}{*}{ TOTAL } \\
\hline & \multirow[b]{2}{*}{$\begin{array}{l}\text { With } \\
\text { Freeway }\end{array}$} & \multirow[b]{2}{*}{$\begin{array}{l}\text { Without } \\
\text { Freeway }\end{array}$} & \multicolumn{2}{|c|}{$\begin{array}{l}\text { Adjacent to } \\
\text { SMSA }\end{array}$} & \multicolumn{2}{|c|}{$\begin{array}{c}\text { Other Nonmetro. } \\
\text { Areas }\end{array}$} & \\
\hline & & & $\begin{array}{c}\text { With } \\
\text { Freeway }\end{array}$ & $\begin{array}{l}\text { Without } \\
\text { Freeway }\end{array}$ & $\begin{array}{l}\text { With } \\
\text { Freeway }\end{array}$ & $\begin{array}{l}\text { Without } \\
\text { Freeway }\end{array}$ & \\
\hline $\begin{array}{l}\text { Net Migration- } \\
\text { Natural Increase }\end{array}$ & 7 & 1 & 13 & 20 & 29 & 52 & 122 \\
\hline $\begin{array}{l}\text { Net Out-Migration } \\
\text { Natural Increase }\end{array}$ & 3 & & 14 & 30 & 34 & 78 & 159 \\
\hline $\begin{array}{l}\text { Net In-Migration } \\
\text { Natural Decrease }\end{array}$ & 0 & 0 & & 2 & 2 & 7 & 11 \\
\hline \multirow[t]{2}{*}{ TOTAL } & 10 & 1 & 27 & 52 & 65 & 137 & 292 \\
\hline & \multicolumn{2}{|c|}{11} & \multicolumn{2}{|c|}{79} & \multicolumn{2}{|c|}{202} & 292 \\
\hline
\end{tabular}


The interplay of economic and demographic factors, particularly the excessive dependency on agriculture for a large number of rural dwellers where fertility remained high, had led to rapid out-migration from rural farm areas, especially of blacks, in the South as technological displacement occurred. Despite the large number of counties that lost population in the 1950 's and 1960's, of which more than 65 percent were in the South, the rural population nationally has remained around 53 million persons. This apparent contradiction between population losses in more than 1,300 counties in the United States in the 1960's, most of which were nonmetropolitan, and the fact that the rural population held steady for the two decades, led to a more intensive examination of the population dynamics at work in the turn-around counties. This research, then, concentrates on the sources of growth, that is, whether growth was due primarily to natural increase (excess of births over deaths) or to net in-migration into the turn-around counties between 1960 and 1970 after losses had occurred therein between 1950 and 1960.

After identifying the components of change in each of the counties or equivalent units in the United States by race where data were available, we were also able to determine not only which counties were turn-around counties but the primary source of the reversal and the differences by race (Table 4). Moreover, operationally defining a strong turn-around county as one growing faster than the national rate of 13.3 percent for the decade, a marginal turn-around county as one growing 5-13.3 percent for the decade, and a borderline turn-around county as one growing less than five percent for the decade after losses in the 1960's, we further categorized counties by the source of that growth (Table 5). Counties reversing losing trends primarily through natural increase, but still having net out-migration, are less likely to continue growth patterns than a county reversing a losing trend through net in-migration and natural increase, or through net in-migration only. This paper concentrates on the components of change for the turn-around counties of the South.

\section{SOUTHERN TURN-AROUND COUNTIES}

Once considered the number one economic problem of the nation and the seed-bed for migrants to other parts of the country, the South has now become the fastest growing region in the nation (Current Population Reports, P-25, No. 508). In fact, the growth rate of the South is more than 50 percent higher than the rest of the nation and almost four times that of the Northeast and the North Central regions. Selective as this growth may be in location, it is important to realize that it is due almost as much to net in-migration as to natural increase. Between 1950 and 1960 more than 750 counties in the South lost population, but between 1960 and 1970 the number of counties with overall loss of population had been reduced to 503, and 292 county units had reversed the loss trend of the 1950's. 
TABLE 4

Southern Counties by Type of Population Change, Blacks and Other Races, 1950-60 and 1960-70*

\begin{tabular}{|c|c|c|c|c|c|c|c|c|c|}
\hline \multirow[t]{2}{*}{ Population Change } & \multicolumn{4}{|c|}{ Increase } & \multicolumn{4}{|c|}{ Decrease } & \multirow{2}{*}{$\begin{array}{l}\text { Row } \\
\text { Total } \\
1950-60\end{array}$} \\
\hline & $a$ & $b$ & $c$ & Total & $x$ & $y$ & $z$ & Total & \\
\hline \multicolumn{10}{|l|}{ Increase: $1950-60$} \\
\hline $\begin{array}{l}a \text {-Net in-migration and } \\
\text { natural increase } \\
b \text {-Net out-migration, } \\
\text { natural increase } \\
\text { greater than net }\end{array}$ & 43 & 38 & - & 81 & - & - & 6 & 6 & 87 \\
\hline $\begin{array}{l}\text { out-migration } \\
\text { c-Net in-migration, } \\
\text { natural decrease less }\end{array}$ & 21 & 137 & - & 158 & - & - & 121 & 121 & 279 \\
\hline than net in-migration & - & - & - & - & - & - & - & - & - \\
\hline Total & 64 & 175 & - & 239 & - & - & 127 & 127 & 366 \\
\hline \multicolumn{10}{|l|}{ Decrease: $1950-60$} \\
\hline $\begin{array}{l}x \text {-Net out-migration and } \\
\text { natural decrease } \\
y \text {-Net in-migration, } \\
\text { natural decrease } \\
\text { greater than }\end{array}$ & - & - & - & - & - & - & - & - & - \\
\hline $\begin{array}{l}\text { net in-migration } \\
z \text {-Net out-migration, } \\
\text { natural increase less }\end{array}$ & - & 一 & - & - & - & - & - & - & 一 \\
\hline than net out-migration & 14 & 53 & 1 & 68 & - & - & 372 & 372 & 440 \\
\hline Total & 14 & 53 & 1 & 68 & - & - & 372 & 372 & 440 \\
\hline \multicolumn{10}{|l|}{ Colurnn Total } \\
\hline $1960-70$ & 78 & 228 & 1 & 307 & - & - & 499 & 499 & 806 \\
\hline
\end{tabular}

*Includes only those counties in which blacks and other races represent ten percent or more of the 1960 population or at least 10,000 population in 1960.

Source: University of Georgia, NSF-RANN Population Redistribution Project.

TABLE 5

Turn-Around Counties of the South by Percent

Change in Total Population, 1.960-1970

\begin{tabular}{|c|c|c|c|c|c|c|c|}
\hline \multirow{3}{*}{$\begin{array}{l}\text { POPULATION } \\
\text { CHANGE } \\
\text { SOURCE }\end{array}$} & \multicolumn{6}{|c|}{ Percent Change in Population } & \multirow{3}{*}{ TOTAL } \\
\hline & \multicolumn{2}{|c|}{$0-5 \%$} & \multicolumn{2}{|c|}{$5-13.3 \%$} & \multicolumn{2}{|c|}{$\begin{array}{l}13.3 \% \\
\text { or More }\end{array}$} & \\
\hline & $\mathbf{N}$ & Pet. & $\mathbf{N}$ & Pct. & $\mathbf{N}$ & Pct. & \\
\hline Net In-Migration & & & & & & & \\
\hline Natural Increase & 7 & 5.7 & 56 & 45.9 & 59 & 48.4 & 122 \\
\hline $\begin{array}{l}\text { Net Out-Migration } \\
\text { Natural Increase }\end{array}$ & 112 & 70.4 & 44 & 27.7 & 3 & 1.9 & 159 \\
\hline Net In-Migration & & & & & & & \\
\hline Natural Decrease & 5 & 45.5 & 2 & 18.2 & 4 & 36.3 & 11 \\
\hline T'OTAL & 124 & & 102 & & 66 & & 292 \\
\hline
\end{tabular}


Of these 292 turn-around counties, 122 gained population through both net in-migration and natural increase, ${ }^{1}$ slightly more than half (159) grew through natural increase exceeding the net out-migration, ${ }^{2}$ and in the other 11 counties net in-migration exceeded natural decrease (Table 2 ). Although the total population in these counties is less than 12 percent of the total population of the South, the significance of the change lies in the fact that there appears to be a rejuvenation as well as a redistribution occurring.

The counties that have reversed the pattern of loss by growth through natural increase only are generally borderline in the strength of that growth; that is, their growth rate was less than five percent for the decade, as net out-migration persisted (Table 5). Counties that have reversed their loss pattern primarily through net in-migration, however, grew at the rate of 18.3 percent for the decade, considerably stronger growth than the natural increase turn-around counties. Still, this growth rate is less than that of the Southern counties that grew for both the past two decades $(28.7 \%)$.

Counties experiencing a sudden spurt of growth in the 1960's after loss in the 1950's have done so primarily because of employment changes in industry and manufacturing that have encouraged migration from the rural countryside and have thus provided an alternative to agriculture as a principal source of income for resident families. A considerable number, particularly in Northwest Arkansas and Eastern Oklahoma, appear to be developing as retirement communities.

Counties reversing their trend primarily through natural increase but still having net out-migration for the decade retain a major dependency on agriculture, although some light manufacturing and availability of other job alternatives may have discouraged the extensive out-migration that had occurred during earlier periods. Many of these natural increase turn-around counties are close enough to other counties where jobs are available for workers to commute without too much difficulty. For example, Clarke County, Georgia, the site of the University of Georgia and several large corporate manufacturing plants, including DuPont, General Time, Westinghouse, and Kendall, is bordered by four turnaround counties (Madison, Oconee, Jackson, and Banks) and one county (Oglethorpe) which lost population for the last three decades. These turn-around counties all had a net out-migration of blacks for the 1960-1970 decade, but there was some in-migration of whites as well as growth through natural increase. Only one-fourth of the workers in Oconee County worked within that county at the census period, while less than a third of those in Jackson and Banks Counties worked in their respective counties. Similar results are found in examining the turnaround counties surrounding Macon, Columbus, and Savannah, Georgia; as well as Anniston and Cullman, Alabama; Knoxville, Cookeville, and

1 We shall refer to these as net in-migration turn-around counties for this paper.

2 Referred to as natural increase turn-around counties hereafter. 
Jackson, Tennessee; Austin, Texas; and Gainesville, Florida (U. S. Bureau of Census, PC1, individual state volumes).

Except for counties of Northwest Arkansas and Eastern Oklahoma, in-migration turn-around counties tend to be either industrial growth centers themselves or adjacent to them. While some of this growth may be attributed to a single plant or industry locating in a particular county, the possibility that other industries will similarly locate in these areas remains as the labor force maintains itself, particularly because of the accessibility to other metropolitan areas, and fewer problems with local governmental agencies. Northwest Arkansas appears to be developing as a retirement community, judging from age differences in the preliminary net migration rates (Bowles, et al., 1975).

By way of contrast, natural increase turn-arounds with net outmigration are frequently isolated, have borderline growth rates, and still have a heavy dependency on agriculture. Moreover, the age dependency ratios are considerably higher in these counties than in either sustained growth counties or net in-migration turn-around counties (Table 6). With these characteristics, the chances of continued growth for the future are quite small. There will be exceptions, of course, most notably, those natural increase counties that now border on the interstate highway system and are proximate to other industrial growth centers.

\section{TURN-AROUND COUNTIES AND RACE}

There has been a major decline of the black population in nonmetropolitan counties of the South for each decade between 1940 and 1970. The estimate of the decline for the 1960-1970 decade is around 40 percent (Bowles, et al, 1973). While the black population is growing rapidly in some metropolitan areas of the South, most notably Atlanta, Houston, Dallas, Washington, D.C., Baltimore, and Memphis, in other areas there has been a net out-migration for the decade, for example, in Birmingham and New Orleans. With very few exceptions, the net in-migration turnaround counties of the South were changed by white in-migration exceeding black out-migration, with the proportion of black residents in these counties often dropping dramatically. In some counties bordering metropolitan areas, for example, DeSoto County, Mississippi (Memphis) and Lee County, Georgia (Albany), the proportion of blacks in the total population dropped more than 50 percent in one decade.

While there are 122 counties in the South that turned from loss to gain through net in-migration and natural increase, in only 14 counties was this true of the nonwhite population. Nire of these were located in Oklahoma and Texas, in counties with a sizable Indian population. Turnaround counties for the black population were counties which turned primarily through natural increase exceeding net out-migration.

Although the black population has declined proportionately in most net in-migration turn-around counties, the amount of total growth in 
these areas was unanticipated. The net in-migration counties grew by more than 18 percent for the decade from 2.04 million to 2.4 million. This represents a 38 percent faster growth rate than that for the rest of the nation for the period. The natural increase turn-around counties grew only 11.3 percent, from 2.8 million to 3.1 million, somewhat less than the national rate.

Only four of the 122 net in-migration turn-around counties of the South experienced the same pattern of change for both whites and blacks, and seven of the 159 natural increase turn-arounds did so. The differential patterns of migration of blacks and whites in the South is not new, but the implications for changing social relationships between races needs more in-depth research. Beale argues, for example, that the net out-migration of rural blacks will reach its nadir within the decade (Beale, 1966). There is some evidence to support this contention as life opportunities in central cities of metropolitan areas are diminished for rural migrants due to the labor surpluses created by the natural increase in central cities, and by the net in-migration of young blacks often without the skills needed for successful competition, and the movement of industrial development to suburban fringe areas. Interestingly, our data show that despite the differences in components of population change in the turn-around counties between blacks and whites, when taken together the net in-migration counties also show a black population increase for the decade of 30,000 or approximately a 13.3 percent growth rate, but there was an overall loss of some 10,000 persons in the natural increase turn-around counties. This would indicate that although there is black out-migration from turn-around counties it is not drastically larger than the natural increase occurring therein.

Generally, net in-migration turn-around counties had low proportions $(<15 \%)$ of blacks to begin the decade. The natural increase turn-arounds, on the contrary, had comparatively high proportions of blacks, 20 percent or more of the population. These counties, too, have very high labor force replacement ratios for blacks (Bowles, 1973). Thus, given the normal reluctance of industries to move into those areas with blacks constituting a considerable proportion of the work force and the high replacement rates, we would argue that the natural increase turn-around counties of the South generally will revert back to population loss for the 1970-1980 decade, barring some other incentive to attract industrial development or national policy stressing the development of these areas.

\section{DEPENDENCY RATIOS AND POVERTY LEVELS}

A demographic index of the economic viability of an area is the dependency ratio. This ratio presents the number of youths (under age 15) and the number of elderly persons (ages 65 and over) for 100 persons in the more economically productive ages (15-64 years). The youth dependency ratio for the United States in 1970 was 46.2, the aged depen- 
dency ratio was 16.0 for a total dependency ratio of 62.6 . The South had a slightly higher youth dependency, 46.9, and slightly lower aged dependency ratio of 15.6 (Lee, et al, 1972).

The turn-around counties of the South are characterized by vast differences in the dependency ratios for both the young and the aged (Table 6). More than two-thirds of the net in-migration turn-around counties had youth dependency ratios lower than the national or southern level, but slightly more than one-third of the natural increase turn-around counties were thus characterized. Both types of turn-around counties had aged dependency ratios well above the national level, as more than 80 percent of the natural increase counties exceeded the national level, and a surprising 90 percent of the net in-migration turn-arounds did so.

The importance of the differences between types of turn-around counties is evident from the fact that the natural increase turn-arounds have both much higher aged dependency and youth dependency ratios than either national or southern levels. The net in-migration turnarounds have a higher level of aged dependency, but a lower level of youth dependency ratios reflecting higher levels of net economic productivity in the latter compared with the former. As previously indicated, a considerable number of the net in-migration turn-around counties of Arkansas have specifically attracted migrantis at the retirement age level.

Given these differential dependency ratios, it is no great surprise to find that the turn-around counties had a disproportionate share of their families with incomes below the poverty level in 1969. In the United States about one-tenth of all families had incomes less than the poverty level, but in the South the proportion was one-eighth (U. S. Bureau of Census, PC (1)-C1, Tables 95 and 135). Among the turn-around counties more than half the net in-migration counties had 20 percent or more of their families with incomes less than the poverty level, and four-fifths of

TABLE 6

Dependency Ratios, Youth and Aged, for Turn-Around Counties South, 1970

\begin{tabular}{|c|c|c|c|c|c|c|c|}
\hline \multirow{2}{*}{$\begin{array}{c}\text { Type of } \\
\text { Turn-Around } \\
\text { County }\end{array}$} & \multicolumn{4}{|c|}{ Youth Dependency Ratios } & \multicolumn{3}{|c|}{ Aged Dependency } \\
\hline & $<46.2$ & $46.2-50$ & $50-60$ & $\begin{array}{l}60 \& \\
\text { Over }\end{array}$ & $<16$ & $16-20$ & $\begin{array}{l}20 \& \\
\text { Over }\end{array}$ \\
\hline $\begin{array}{l}\text { Net } \\
\text { In-Migration }\end{array}$ & 85 & 19 & 17 & 1 & 13 & 28 & 81 \\
\hline \multirow[t]{2}{*}{$\begin{array}{l}\text { Natural } \\
\text { Increase }\end{array}$} & 60 & 45 & 49 & 5 & 24 & 59 & 76 \\
\hline & \multicolumn{4}{|c|}{$\begin{array}{l}\text { U. S. Ratio } 46.2 \\
\text { South Ratio } 46.9\end{array}$} & \multicolumn{3}{|c|}{$\begin{array}{l}\text { U. S. Ratio } 16.0 \\
\text { South Ratio } 15.6\end{array}$} \\
\hline
\end{tabular}

Source: E. S. Lee, et al., Demographic Profiles of the United States, Oak Ridge National Laboratory, Oak Ridge, Tennessee, 1972. 
the natural increase counties fell into this category (Table 7). The net in-migration counties are characterized by considerably less poverty than the natural increase turn-arounds, but are still well above both the national and southern level averages of families with incomes under the poverty level.

\section{CONCLUSIONS}

The ease with which one can attract an audience by projecting national growth rates and associated growth problems without examining specifics of population distribution has been made abundantly clear by Ehrlich (1971), the Paddocks (1967), and others such as the Zero Population Growth and Planned Parenthood World Population groups. To those who must contend with day-to-day problems of transportation, pollution, unemployment, environmental destruction, etc., these projections become especially heartrending. Yet, despite dire predictions of overpopulation more than one-third of the counties in the United States lost population each of the last two decades, and an additional 300 lost population from 1960 to 1970 . Some 480 counties turned around from population loss to population gain during the latter decade. This de-population has occurred principally in nonmetropolitan areas. Once inhabitable and productive areas have thus become de-populated as the economic opportunity base has shifted.

For the South de-population has occurred largely because of the continued out-migration of black population. As a nation we have wasted much of our human resources, as well as our natural resources. Now that

\section{TABLE 7}

Percent of Families with Income Less than Poverty Level in 1969 for Turn-Around Counties of the South

\begin{tabular}{|c|c|c|c|c|c|}
\hline \multirow{2}{*}{$\begin{array}{c}\text { Type of } \\
\text { Turn-Around } \\
\text { County }\end{array}$} & \multicolumn{4}{|c|}{$\begin{array}{l}\text { Percent Families with Income } \\
\text { Less than Poverty Level }\end{array}$} & \multirow{2}{*}{ TOTAL } \\
\hline & $<16.2$ & $16.2-20$ & $20-25$ & $25+$ & \\
\hline $\begin{array}{l}\text { Net Migration } \\
\text { Natural Increase }\end{array}$ & 22 & 31 & 38 & 31 & 122 \\
\hline $\begin{array}{l}\text { Net Out-Migration } \\
\text { Natural Increase }\end{array}$ & 10 & 17 & 43 & 89 & 159 \\
\hline $\begin{array}{l}\text { Net In-Migration } \\
\text { Natural Decrease }\end{array}$ & 4 & 3 & 2 & 2 & 11 \\
\hline \multirow[t]{2}{*}{ TOTAL } & 36 & 51 & 83 & 122 & 292 \\
\hline & \multicolumn{4}{|c|}{$\begin{array}{l}\text { South: } 16.2 \\
\text { U. S.: } 10.7\end{array}$} & \\
\hline
\end{tabular}

Source: U. S. Bureau of Census, Census of Population: 1970, PC(1)-C1 and related state volumes, General Social and Economic Characteristics, Washington, D. C.: U.S. Government. 
some national policies are achieving a degree of success in such areas as reforestation, increased efficiency and productivity in agriculture, and even planned development of metropolitan fringe areas, we have the ability, too, to utilize better our human resources.

In the net in-migration turn-around counties re-population is occurring. The natural increase turn-around counties, however, are growing much less quickly and are not likely to continue without changes in the economic base that would not only hold the existing population but also attract population from other areas. Most of the turn-around counties of the South were either borderline or marginal in their growth patterns. Yet, the evidence of movement into selected areas and the development of economic opportunity in these areas would indicate a strong possibility for continued growth in the South in the future. Certainly the South has a proportionate share of areas of natural beauty and with its favorable climatic conditions is potentially a very attractive place for rural development. Labor force replacement ratios are still high in the South and the increasing educational attainment of Southerners, be they black or white, provides the necessary human resource base for maximum development in nonmetropolitan areas.

Because of the favorable locations of net in-migration turn-around counties growth in these areas probably will continue. Although it is not possible with existing data to demonstrate conclusively the full impact of the interstate highway system on the growth patterns of the turnaround counties, the growth rates of those counties on or adjacent to the freeway system is higher than those not on the system. Considering that large segments of the interstate highway system had not been opened at the time of the 1970 Census, the full impact may not be known for another five years or more. Certainly increased accessibility to metropolitan areas has opened many nonmetropolitan areas for growth that had been previously ignored by industries.

Examination of the demographic characteristics of the turn-around counties indicates the willingness of the population to move into those areas where economic opportunities are made available regardless of their rural or nonmetropolitan character. Other areas have grown through natural increase without much change in the economic base on which they are operating, resulting in continued out-migration. Such areas in the South are characterized by high youth and age dependency ratios, high proportions of black populations, and limited access to metropolitan areas. With high labor force replacement ratios and comparatively little economic or educational opportunity in these natural increase counties, most will probably revert to losing population during the ensuing decade. Economic growth and subsequent population growth in nonmetropolitan areas of the South will probably occur near freeways in those areas with greatest accessibility to metropolitan areas. Whether this growth will be aesthetically appealing and rational depends largely on how the existing policies are implemented and what new policies are adopted. 


\section{REFERENCES}

Beale, Calvin. "The Negro in American Agriculture," in The American Negro Reference Book, John B. Davis, Editor, Prentice-Hall, Englewood Cliffs, N. J., 1966.

Beale, Calvin. "Needed Rural Population Research," in Research and the 1970 Census, Abbott L. Ferriss, Editor, Southern Regional Demographic Group, Oak Ridge Associated Universities, Oak Ridge, Tenn., 1971.

Beckman, Norman and Susan Harding. "National Urban Growth Policy: 1972 Congressional and Executive Action," Journal of the American Institute of Planners, Vol. XXXIX, No. 4, July, 1973.

Bowles, Gladys K. and James D. Tarver. Net Migration of the Population, 1950-60, by Age, Sex, and Color, Vol. II, Analytical Groupings of Counties, U. S. Department of Agriculture, Economic Research Service, Washington, D.C., 1965.

Bowles, Gladys K. and others. Potential Supply and Replacement of Rural Males of Labor Force Age, 1960-70, Statistical Bulletin, No. 378, U. S. Department of Agriculture, Economic Research Service, Washington, D.C., 1966.

Bowles, Gladys K., A Lloyd Bacon and P. Neal Ritchey. Poverty Dimensions of Rural to Urban Migration: A Statistical Report,
U. S. Government Printing Office, Washington, D.C., 1973.

Bowles, Gladys K. Preliminary Labor Force Replacement Ratios for Counties, 1970-1980 -unpublished, 1973.

Ehrlich, Paul. The Population Bomb, Ballantine Books, New York, 1971.

Hansen, Niles. The Future of Nonmetropolitan America, Lexington Brooks, Lexington, Mass., 1973.

Lee, Everett S. and others. Demographic Profiles of the United States, Oak Ridge National Laboratory, Oak Ridge, Tenn., 1972.

Lee, Everett S. "National Policies Explicit and Implicit: Their Implications for Social Change." Unpublished paper presented at the Annual Meeting of Rural Sociological Society, University of Maryland, College Park, Md., 1973.

Paddock, William and Paul Paddock. Famine 1975! America's Decision: Who Will Survive? Little Brown \& Co., Boston and Toronto, 1967.

U.S. Bureau of Census. PC(1)-C1, 1970 Census of Population, General Social and Economic Characteristics, U. S. Summary, and related state volumes, 1970.

Current Population Reports, P-25, No. 508, 1973. 